\title{
DIET SHIFTS RELATED TO BODY SIZE OF THE PIRAMBEBA Serrasalmus brandtii LÜTKEN, 1875 (OSTEICHTHYES, SERRASALMINAE) IN THE CAJURU RESERVOIR, SÃO FRANCISCO RIVER BASIN, BRAZIL
}

\author{
OLIVEIRA, A. K., ${ }^{1}$ ALVIM, M. C. C., ${ }^{2}$ PERET, A. C. ${ }^{2}$ and ALVES, C. B. M. ${ }^{3}$ \\ ${ }^{1}$ Departamento de Ecologia e Biologia Evolutiva, Universidade Federal de São Carlos, Rod. Washington Luís, \\ km 235, CEP 13565-905, C.P. 676, São Carlos, SP, Brazil \\ ${ }^{2}$ Departamento de Hidrobiologia, Universidade Federal de São Carlos, Rod. Washington Luís, km 235, \\ CEP 13565-905, C.P. 676, São Carlos, SP, Brazil \\ ${ }^{3}$ Departamento de Zoologia, Universidade Federal de Minas Gerais, Av. Antônio Carlos, 6627, \\ CEP 31270-901, Belo Horizonte, MG, Brazil \\ Correspondence to: Alexandre K. Oliveira, Departamento de Ecologia e Biologia Evolutiva, \\ Universidade Federal de São Carlos, Rod. Washington Luís, km 235, CEP 13565-905, C.P. 676, \\ São Carlos, SP, Brazil, e-mail: pako@iris.ufscar.br \\ Received September 17, 2002 - Accepted March 10, 2003 - Distributed February 29, 2004
}

(With 6 figures)

\begin{abstract}
This study aimed to identify shifts in the Serrasalmus brandtii Lütken, 1875 diet related to body size. Specimens were collected from April 1992 to January 1993 at the Cajuru Reservoir, in the Pará River, São Francisco River Basin, by seining the shore with nets of nylon, $1 \mathrm{~mm}$ opening, and with gill nets. Stomach contents of 152 individuals measuring 15-192 mm SL were examined. Food items were identified and weighed separately. For qualitative analysis, the frequency of occurrence method was used. The relative importance of each food component was determined based on the alimentary in$\operatorname{dex}\left(\mathrm{IA}_{\mathrm{i}}\right)$. The frequencies of occurrence data were subjected to cluster analysis using the Canberra coefficient of dissimilarity and UPGMA as the cluster method. Distinctive gradual changes in food habits, associated with body size, were identified in this species. The smaller individuals fed predominantly on microcrustaceans and insect larvae. The intermediate size classes ingested insects, fish fins, fish scales, and chunks of fish flesh, in this order of importance. For the larger pirambebas, fish was the most abundant food category identified, followed by insects.
\end{abstract}

Key words: Serrasalmus brandtii, body size, trophic ecology, reservoir, similarity.

\section{RESUMO}

Modificações na dieta da pirambeba Serrasalmus brandtii Lütken, 1875

(Osteichthyes, Serrasalminae), em relação ao tamanho corpóreo no reservatório Cajuru, bacia do rio São Francisco, Brasil

Este estudo teve por objetivo identificar mudanças na dieta de Serrasalmus brandtii Lütken, 1875, em função do tamanho corporal. Os peixes foram coletados no reservatório Cajuru, rio Pará, bacia do rio São Francisco, por meio de arrastos na região litorânea e de redes de emalhar, entre abril de 1992 e janeiro de 1993. Foram analisados os conteúdos estomacais de 152 indivíduos, medindo 15$192 \mathrm{~mm}$ CP. Os itens alimentares foram identificados e pesados separadamente. Para análise qualitativa aplicou-se o método de freqüência de ocorrência e para análise da importância relativa das categorias alimentares na dieta, o índice alimentar $\left(\mathrm{IA}_{\mathrm{i}}\right)$. Os dados de freqüência de ocorrência dos itens foram submetidos à análise de agrupamento, utilizando coeficiente de dissimilaridade de Canberra e UPGMA como forma de agrupamento. Evidenciaram-se modificações graduais e marcantes na dieta em função do tamanho corporal dessa espécie. Os indivíduos menores alimentaram-se predominantemente de 
microcrustáceos e larvas de insetos; as classes intermediárias ingeriram insetos, nadadeiras, escamas e pedaços da musculatura de peixes; já as pirambebas maiores, peixes e insetos, respectivamente, foram as categorias alimentares mais abundantes.

Palavras-chave: Serrasalmus brandtii, tamanho corporal, alimentação de peixes, reservatório, similaridade

\section{INTRODUCTION}

Piranhas and pirambebas are widely spread fishes in South America that proliferate in lentic environments (Barbosa, 1980). They have piscivorous habits (Nico \& Taphorn, 1988; Braga, 1975; Northcote et al., 1986; Bistoni \& Haro, 1995) and are known to be mutilating predators, feeding on fish fins, scales, and other body parts of their prey (Goulding, 1980; Leão et al., 1991; Machado-Allison \& Garcia, 1986; Nico \& Taphorn, 1988; Northcote et al., 1987). The body growth of these fish is followed by morphological changes (MachadoAllison \& Garcia, 1986) that influence their food habits (Winemiller, 1989), accounting for the different trophic levels occupied by them during their life history.

The purpose of this work was to evaluate the ecological role played by individuals of different sizes of the pirambeba Serrasalmus brandtii Lütken, 1875 in the Cajuru Reservoir through the analysis of their stomach contents.

\section{MATERIAL AND METHODS}

\section{Study area}

The Cajuru Hydroelectric Power Plant reservoir belongs to the Companhia Energética de Minas Gerais (CEMIG) (Fig. 1) and is located at Carmo do Cajuru, in Divinópolis and Cláudio counties. This reservoir was formed in 1959 by damming the Pará River, one of the main tributaries of the upper São Francisco River (Cetec, 1983). Its total flooded area is $27 \mathrm{~km}^{2}$ and its maximum stored water volume is $192 \times 10^{6} \mathrm{~m}^{3}$ (Mello, 1978). Studies of fishes feeding at this reservoir have already been developed for the Cheirodontinae subfamily species Serrapinnus heterodon (Eingenmann, 1915) (Alvim et al., 1997, 1998) and for young Serrasalmus brandtii (Alvim et al., 1999).

\section{The species studied}

The pirambeba $S$. brandtii (Fig. 2) has been reported for the São Francisco River Basin (Britski et al., 1988) and for the northeastern river basins of Brazil (Magalhães et al., 1990; Braga, 1975). As do other species of the Serrasalminae subfamily, S. brandtii possesses a single series of tricuspid and cutting teeth in the pre-maxillary and dentary bones, and compressed and high body shape (Britski et al., 1988).

Locally also referred to as "cavaca", the pirambeba $S$. brandtii is one of the most abundant species in the Cajuru Reservoir (Alves, 1995). The collected specimens of $S$. brandtii are deposited in the Museu de Zoologia da Universidade de São Paulo and registered as MZUSP 51468 and MZUSP 51478.

\section{Methods}

Fish specimens were collected from April 1992 to January 1993 with a seine $($ mesh size $=1 \mathrm{~mm})$ on the shore and with gill nets (mesh size from 30 to $160 \mathrm{~mm}$ between opposing knots). Immediately after capture, the fishes were fixed in $10 \%$ formalin solution and then preserved in $2 \%$ formalin solution until dissection.

In the laboratory, 152 specimens were weighed, measured (Standard Length), and had their stomach contents examined under a stereomicroscope. Food items were identified and weighed separately. The specimens were grouped into size classes, each one with a representative number of individuals and coefficient of variation (CV) not exceeding $16 \%$. Quantitative analysis was performed based on the stomach repletion degree $(\overline{\mathrm{GR}})$, according to Santos (1978) (Expression 1). The frequency of occurrence (Hyslop, 1980) was used for analyzing the diet qualitatively. The relative importance of each food category was determined using the alimentary index $\left(\mathrm{IA}_{\mathrm{i}}\right)$, according to Kawakami \& Vazzoler (1980) with changes (Expression 2).

$$
\begin{gathered}
\overline{\mathrm{GR}}=\frac{\left(0 \mathrm{n}_{0}+1 \mathrm{n}_{1}+2 \mathrm{n}_{2}+3 \mathrm{n}_{3}\right)}{\left(\mathrm{n}_{0}+\mathrm{n}_{1}+\mathrm{n}_{2}+\mathrm{n}_{3}\right)} \\
\mathrm{IAi}=\frac{\mathrm{Fi} \times \mathrm{Pi}}{\sum_{\mathrm{i}=1}^{\mathrm{n}}(\mathrm{Fi} \times \mathrm{Pi})} \times 100
\end{gathered}
$$


where:

$\overline{\mathrm{GR}}=$ stomach repletion degree;

$\mathrm{n}_{0} \quad=$ number of specimens with degree of repletion 0 ;

$\mathrm{n}_{1} \quad=$ number of specimens with degree of repletion 1 ;

$\mathrm{n}_{2} \quad=$ number of specimens with degree of repletion 2;

$\mathrm{n}_{3}=$ number of specimens with degree of repletion 3;

IAi = alimentary index;

$\mathrm{Fi}=$ relative frequency of occurrence of food category i;

$\mathrm{Pi}=$ relative gravimetric participation of food category i.
The absolute frequencies of all food items obtained for each size class were subjected to cluster analysis using the Canberra dissimilarity coefficient, and UPGMA as clustering method, using the NTSYS-PC 2.0 program (Exceter Software). The cophenetic correlation coefficient ( $\mathrm{r}$ ) was calculated to evaluate dendrogram deformation in relation to the original distance matrix.

\section{RESULTS}

The 152 specimens measured from 15 to 192 $\mathrm{mm}$ SL were grouped into eight size classes. Only three individuals had empty stomachs, and no size classes showed a $\overline{\mathrm{GR}}$ of less than 1.5 (Fig. 3).

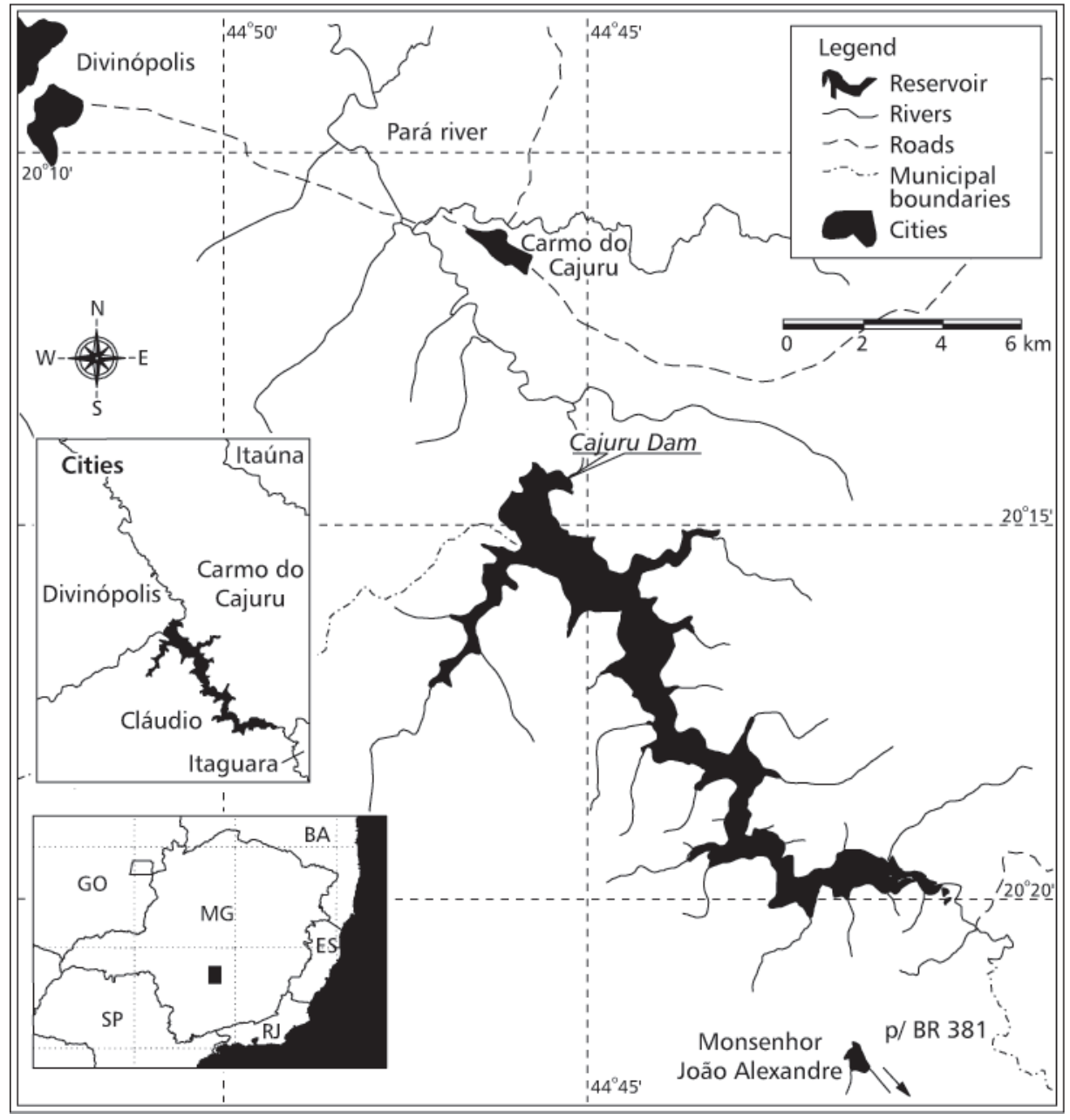

Fig. 1 - Map of the Cajuru Reservoir. 


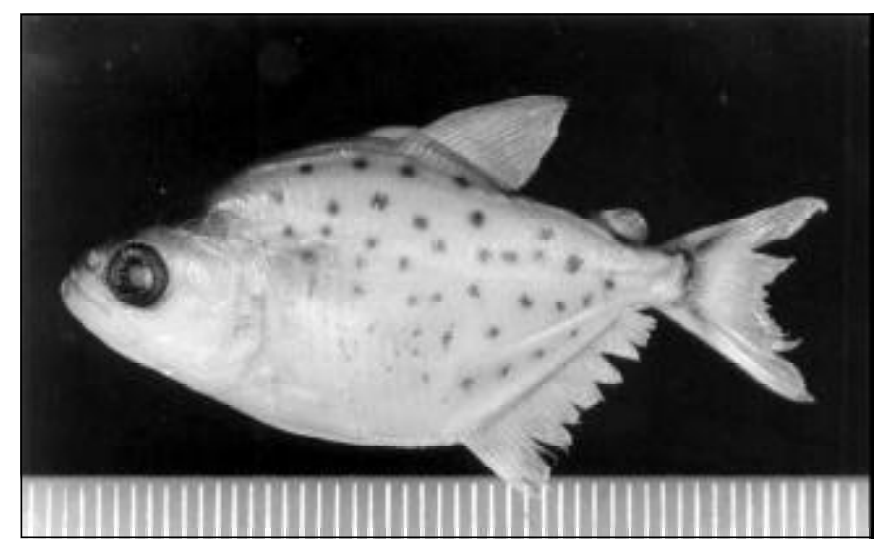

Fig. 2 - Specimen (32 mm standard length) of S. brandtii captured in Cajuru Reservoir.

The pirambeba S. brandtii showed distinctive diet shifts related to body size (Fig. 3). Twenty-two food items were identified and categorized as microcrustaceans, insects, fish, and plant remains. The microcrustaceans included Cladocera, Copepoda (nauplii, copepodids, and adults), and Ostracoda. The insects comprised Chironomidae larvae, larval and adult Coleoptera, Hemiptera, Hymenoptera, Trichoptera, nymphs of Ephemeroptera and Odonata, and parts of other unindentified insects. The fish category consisted of fish fins, fish scales, fish flesh chunks, and small whole fish. The plant remains included seeds, fragments of roots, stalks, and leaves.

Microcrustaceans (the majority of them Cladocera) were the most important alimentary item in the diet of the individuals in the two smallest size classes, but were absent in the stomachs of $S$. brandtii from the 75-95 $\mathrm{mm}$ size class. The smallest pirambebas also ingested insects (e.g., Chironomidae) and fish, though in small intensity. These two food items had a greater importance in the diet of the largest pirambebas, with fish items predominating. The main insects ingested were Chironomidae in the smallest size class (15-25 mm), Ephemeroptera and Odonata nymphs in the intermediate size classes $(25-35 \mathrm{~mm}$ to $115-135 \mathrm{~mm}$ ), and Coleoptera in the largest size class $(\geq 135 \mathrm{~mm}$ ). Plant remains represented only a minor percentage of stomach content in all size classes.

Distinctly piscivorous patterns related to body size were identified (Fig. 4). Already in the smallest size class, the pirambebas fed on fish fins and scales. Fish fins were the major food component in all size classes up to $75-95 \mathrm{~mm}$. Observations on the ichthyocenosis revealed a large number of Tilapia rendalli (Boulenger, 1897) (specimens deposited and registered as MZUSP 51477) individuals with mutilated caudal fins (Fig. 5), indicating that this species is the major prey. The extent of caudal damage ranged from small cuts to total loss of the caudal peduncle. The major items in the diet of the largest pirambebas were fish flesh chunks and whole small fish.

The dendrogram resulting from the cluster analysis revealed five feeding phases (Fig. 6). The smallest size class (phase 1) showed the highest diversity of food items and was separated from the other size classes by a distance of approximately 0.61 .

The 25-35 $\mathrm{mm}$ and 35-55 $\mathrm{mm}$ classes (phase II) formed a sub-group whose food habits were more similar to those of the largest size classes and showed a higher food specificity. The diet of the $55-75 \mathrm{~mm}$ pirambebas (phase III) was also more similar to that of the larger size classes. The 75-95 mm and 95-115 $\mathrm{mm}$ size classes (phase IV) were grouped together with the two largest classes (phase V), as both had very similar diets consisting mainly of fish.

\section{DISCUSSION}

The first two feeding phases (up to $35 \mathrm{~mm}$ ) showed diets consisting of microcrustaceans, Cladocera mostly; insect larvae; fish fins; and fish scales (see Alvim et al., 1999 for details of the smallest-size class diet), similar to other piranhas and pirambebas of comparable size. Nico \& Taphorn (1988) reported the ingestion of microcrustaceans, larvae of Chironomidae, and other invertebrates by Pygocentrus notatus juveniles (10 to $19 \mathrm{~mm}$ ) in the Orinoco River Basin. 


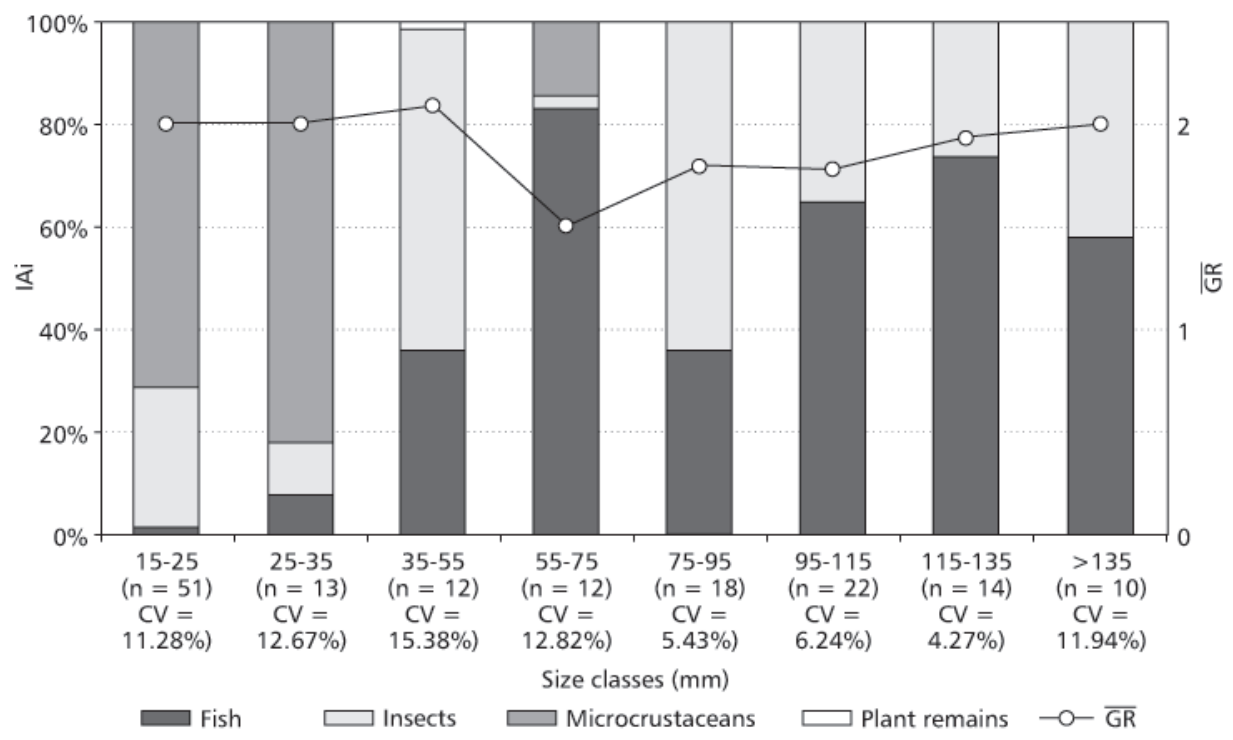

Fig. 3 - Stomach repletion degree $(\overline{\mathrm{GR}})$ and relative importance of preys in the diet of S. brandtii.

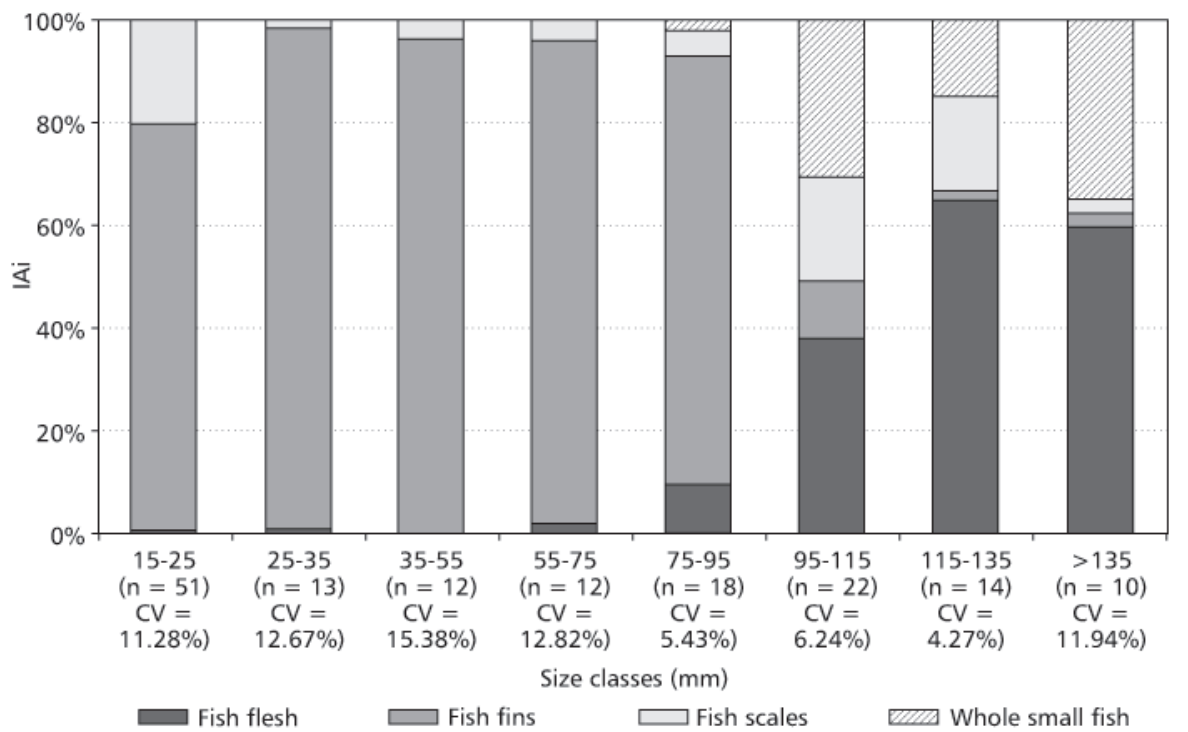

Fig. 4 - Fish-eating habits of $S$. brandtii related to body size.

Machado-Allison \& Garcia (1986) described the diet shifts and morphology of three Serrasalminae (Pygocentrus notatus, Pristobrycon striolatus, and Serrasalmus rhombeus) and found that individuals up to $40 \mathrm{~mm}$ standard length fed intensively on microcrustaceans and insects, and also exhibited mutilating piscivorous habits. Sazima \& Zamprogno (1985) described a similar diet for Serrasalmus spilopleura larvae and juveniles up to $19.5 \mathrm{~mm}$ standard length and observed the presence of pieces of fins of several fish species in the stomachs of individuals measuring more than $24 \mathrm{~mm}$. 
Concerning fin-eating habits, Nico \& Taphorn (1988) found fins of other fish to be an item of major importance in the diet of the young of five species of the Serrasalmus genus. According to Northcote et al. (1986) and Northcote et al. (1987) most of the damage in the fins of fish in the Americana Reservoir (SP) was attributed to $S$. spilopleura individuals that forage near the littoral vegetation. If not "grazed down" too far, fish fins regenerate rapidly and, thus, can be considered a renewable food resource (Northcote et al., 1987). The massive preying on the fins of tilapias may be related to the latter's foraging habit in the river bottom, common in cichlids, which exposes their caudal fins to pirambeba attacks. Northcote et al. (1987) and Sazima \& Pombal-Jr. (1988) also observed massive preying on the caudal fin of other cichlids (Tilapia rendalli and Geophagus brasiliensis) by $S$. spilopleura.

Insectivory and piscivory have been reported for the pirambeba $S$. brandtii. Bedê et al. (1993) found aquatic insects and fish to predominate in $S$. brandtii stomach contents in the Pampulha Reservoir in Belo Horizonte. Magalhães et al. (1990) described an essentially carnivorous diet showing no seasonality, for S. brandtii, it consisted of aquatic and terrestrial insects, crustaceans (decapods) and, preferably, fish. Pompeu (1999), in studying the food habits of S. brandtii in marginal lakes of the São Francisco River, found seasonal and ontogenetic differences in the diet of this species, and related their piscivorous behavior to food available in the environment, attributing an opportunistic feeding habit to the pirambeba.

Plant remains were described as a food item of piranha species in the Amazon (Goulding, 1980) and in Venezuela (Machado-Allison \& Garcia, 1986). The ingestion of plant material by the piranha species studied by Nico \& Taphorn (1988) was considered accidental, i.e., thought to occur secondarily, along with intended prey items. The low consumption of plant remains by $S$. brandtii can be thought of as unintentional, but this requires further studies, because all size classes showed this food category in their gut content.

Cluster analysis allowed the identification of five feeding phases for the size classes of Serrasalmus brandtii studied. The smallest individuals $(15-25 \mathrm{~mm})$ with the greatest food item spectrum were distinguished from the others by a distance of 0.61 . As the individuals' length increases, this distance decreases in the direction of the piscivorous feeding specificity.

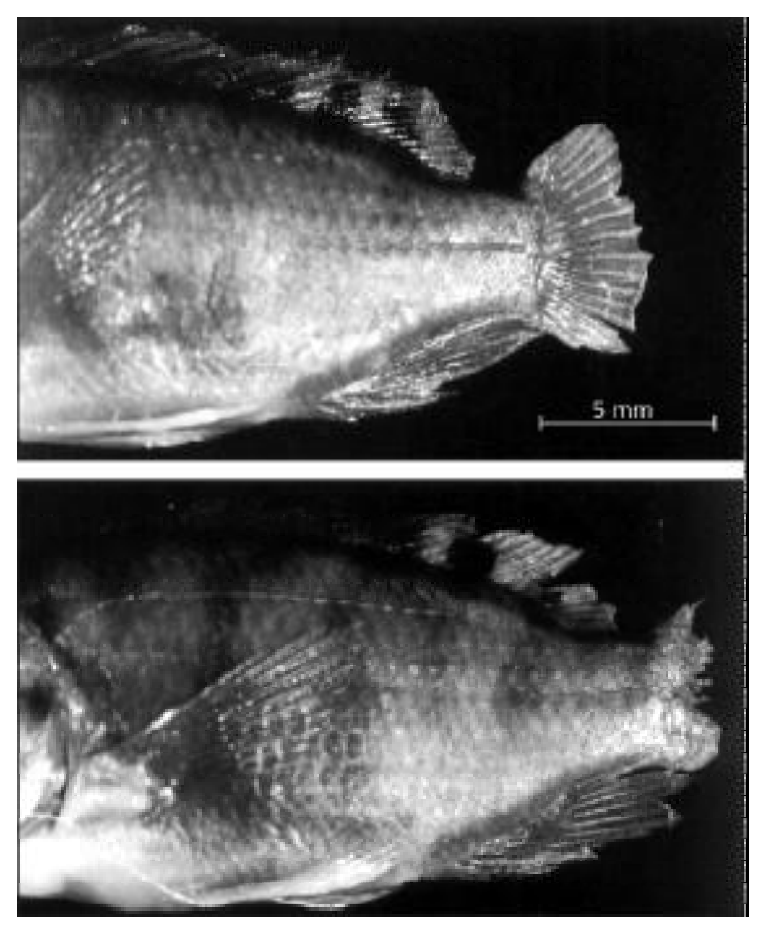

Fig. 5 - Specimens of Tilapia rendalli with mutilated caudal fins, collected in the Cajuru Reservoir. 


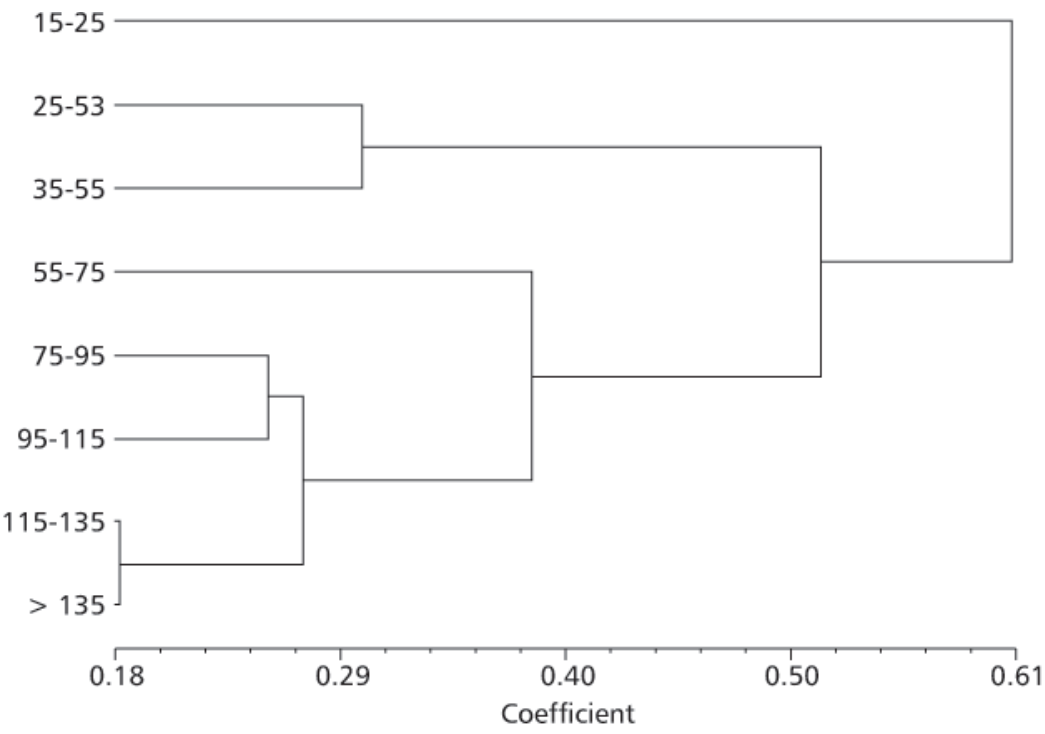

Fig. 6 - Dendrogram resulting from cluster analysis by the UPGMA method, using Canberra metric $(r=0.905)$.

However, there are phases when individuals retain the same feeding characteristics longer. Considering that the biological growth process of individuals describes curves with decreasing inclinations, it can be said that more time is spent on the same size increment. Thus, change in the $S$. brandtii feeding habits in phase I to the next is relatively fast. The change in feeding characteristics of individuals in phase II is slower because they retain the same ones until reaching $55 \mathrm{~mm}$, and the growth curve in this phase probably has a low inclination.

In the next phase, the individuals remain until reaching an increase of $20 \mathrm{~mm}$. In phase IV, they continue until an increase of $40 \mathrm{~mm}$, and in phase $\mathrm{V}$ they are highly similar, because the piscivorous incidence increased substantially, justifying the low difference level. This demonstrates the use of the similarity measure as an instrument to describe diet shift processes of the pirambeba Serrasalmus brandtii at the Cajuru Reservoir as a function of body growth.

Ontogenetic diet shifts have been demonstrated for piscivorous (Machado-Allison \& Garcia, 1986; Nico \& Taphorn, 1988; Winemiller, 1989) and scaleeating (Hahn et al., 2000) tropical fish. Early life stages of these fishes commonly present a diet based on microcrustaceans and insects. This diet gradually changes as morphological changes occur during growth. Species of Serrasalmus genus studied by Winemiller (1989) showed a shift to a diet composed primarily of fish components between 20 and 40 mm. In Cajuru Reservoir young Serrasalmus brandtii of $15 \mathrm{~mm}$ already ingested fish fins, but only from the $55-75 \mathrm{~mm}$ size class fish became the most abundant food category. The zooplankton ingestion extend to sub-adult age, when the Serrasalmus brandtii diet was comprised of insects and fins and chunks of fish. The ingestion of microcrustaceans and insects by $S$. brandtii in its early stages of development on the shoreline of the reservoir is shared by Serrapinnus heterodon (Alvim et al., 1997) and probably with other fish species encountered in this environment, such as Astyanax sp. and other small-sized species of the Characidae family (Alves, 1995), but the diet of these species still needs to be studied. In conclusion, the young Serrasalmus brandtii, which is very abundant on the shoreline of the reservoir, mainly occupy the third trophic level of food chains, as do other fish species that feed on invertebrates. Sub-adults and adults of $S$. brandtii may also occupy a higher trophic level when they ingest small whole fish, but this item is not very abundant, even in the largest size class. Individuals of Serrasalmus brandtii in different, but close, stages of development influence differently each prey population and may constitute distinct functional units in the reservoir. Young Serrasalmus brandtii exert pressure on the populational structure of invertebrate prey, because they ingest whole prey, a function that diminishes as the individuals increase in size and intensify their mutilating piscivorous habits. 
Acknowledgments - The authors gratefully acknowledge Dra. Nelsy Fenerich Verani (UFSCar) for criticism and suggestions on the manuscript. Dra. Susana Trivinho Strixino (UFSCar) helped with insect identification. The Companhia Energética de Minas Gerais (CEMIG) gave logistical support for fish collection necessary for the project of C. B. M. Alves, in fulfilling the requirements for his MS degree during the C. B. M. Alves' master of sciences project.

\section{REFERENCES}

ALVES, C. B. M., 1995, Influência da manipulação artificial da época de enchimento na produtividade ictiofaunística em um reservatório de médio porte - UHE Cajuru, rio Pará $(M G)$ : uma proposta de manejo. Dissertação de Mestrado (Ecologia, Conservação e Manejo de Vida Silvestre), Instituto de Ciências Biológicas, Universidade Federal de Minas Gerais, Belo Horizonte, 64p.

ALVIM, M. C. C., MAIA-BARBOSA, P. M. \& ALVES, C. B. M., 1997, Alimentação de Holoshestes heterodon (Teleostei: Cheirodontinae) do reservatório da Usina Hidrelétrica Cajuru-MG, em relação ao nível da água. Acta Limnol. Brasil., 9: 45-54.

ALVIM, M. C. C., MAIA-BARBOSA, P. M. \& ALVES, C. B. M., 1998, Feeding of Holoshestes heterodon Eigenmann (Teleostei: Cheirodontinae) of the Cajuru Reservoir (Minas Gerais, Brazil), in relation to the vegetal biomass in its depletion zone. Rev. Bras. Zool., 15(4): 995-1002.

ALVIM, M. C. C., OLIVEIRA, A. K., ALVES, C. B. M. \& PERET, A. C., 1999, Diet of young Serrasalmus brandtii (Teleostei: Serrasalminae) from the Cajuru hydroeletric plant reservoir (MG, Brazil), in relation to the vegetal biomass in the depletion zone. Multiciência, 3(2): 94-103.

BARBOSA, J. M., 1980, Ocorrência de peixes da subfamília Serrasalminae (Osteichthyes, Characidae), no Piauí, Brasil. Rev. Nordest. Biol., 3(especial): 91-100.

BEDÊ, L. C., SANTOS, G. B., ALVES, C. B. M. \& PELLI, A., 1993, Alimentação de peixes do reservatório da Pampulha, Belo Horizonte, MG, com ênfase na malacofagia. Ceres, 40: 429-437.

BISTONI, M. A. \& HARO, J. G., 1995, Hábitos alimentarios de Serrasalmus spilopleura (Pisces, Serrasalmidae) en los bañados del Río Dulce (Córdoba, Argentina). Rev. Brasil. Biol., 55(4): 847-853.

BRAGA, R. A., 1975, Ecologia e etologia de piranhas no Nordeste do Brasil (Pisces - Serrasalmus Lacépede, 1803). 2. ed. Banco do Nordeste do Brasil S. A., Ceará, 268p.

BRITSKI, H. A., SATO, Y. \& ROSA, A. B. S., 1988, Manual de identificação de peixes da região de Três Marias. 3. ed. CODEVASF, Brasília, 115p.

CETEC (Fundação Centro Tecnológico de Minas Gerais), 1983, Diagnóstico Ambiental do Estado de Minas Gerais. Série de publicações técnicas/SPT-010, 158p.

GOULDING, M., 1980, The fishes and the forest: explorations in Amazonian Natural History. University of California Press, Berkeley, 280p.
HAHN, N. S., PAVANELLI, C. S. \& OKADA, E. K., 2000, Dental development and ontogenetic diet shifts of Roeboides paranensis Pignalberi (Oteichthyes, Characinae) in pools of the upper Rio Paraná floodplain (State of Paraná, Brazil). Rev. Brasil. Biol., 60(1): 93-99.

HYSLOP, E. J., 1980, Stomach contents analysis - a review of methods and their application. J. Fish Biol., 17: 411-429.

KAWAKAMI, E. \& VAZZOLER, G., 1980, Método gráfico e estimativa de índice alimentar aplicado no estudo de alimentação de peixes. Bolm. Inst. Oceanogr., 29(2): 205-207.

LEÃO, E. L. M., LEITE, R. G., CHAVES, P. T. C. \& FERRAZ, E., 1991, Aspectos da reprodução, alimentação e parasitofauna de uma espécies rara de piranha, Serrasalmus altuvei Ramírez, 1965 (Pisces, Serrasalmidae) do baixo rio Negro. Rev. Brasil. Biol., 51(3): 545-553.

MACHADO-ALLISON, A. \& GARCIA, C., 1986, Food habits and morphological changes during ontogeny in three serrasalmin fish species of the Venezuelan floodplains. Copeia, 1986(1): 193-195.

MAGALHÃES, E. M., ALMEIDA, R. G., GURGEL, H. C. B. \& BARBIERI, G., 1990, Contribuição ao estudo da alimentação de Serrasalmus brandtii (Reinhardt, 1874) (Characiformes, Serrasalmidae) do rio Piranhas-Açu, Pendências, Rio Grande do Norte. Ceres, 37: 429-442.

MELLO, F. M., 1978, Grandes barragens do Brasil. Construção Pesada, 95: 16-230.

NICO, L. G. \& TAPHORN, D. C., 1988, Food habits of piranhas in the low llanos of Venezuela. Biotropica, 20(4): 311-321.

NORTHCOTE, T. G., ARCIFA, M. S. \& FROEHLICH, O., 1987, Fin-feeding by the piranha (Serrasalmus spilopleura Kner): the cropping of a novel renewable source. Proc. V Congr. Europ. Ichthyol., Stockhol, 1985, pp. 133-143.

NORTHCOTE, T. G., NORTHCOTE, R. G. \& ARCIFA, M. S., 1986, Differential cropping of the caudal fin lobes of prey fishes by the piranha, Serrasalmus spilopleura Kner. Hydrobiologia, 141: 199-205.

POMPEU, P. S., 1999, Dieta da pirambeba Serrasalmus brandtii Reinhardt (Teleostei, Characidae) em quatro lagoas marginais do rio São Francisco, Brasil. Rev. Bras. Zool., 16(supl.2): 19-26.

SANTOS, E. P., 1978, Dinâmica de populações aplicada à pesca e piscicultura. HUCITEC; Editora da Universidade de São Paulo, São Paulo, 129p.

SAZIMA, I. \& POMBAL-JR., J. P., 1988, Mutilação de nadadeiras em acarás, Geophagus brasiliensis, por piranhas, Serrasalmus spilopleura. Rev. Brasil. Biol., 48(3): 477-483.

SAZIMA, I. \& ZAMPROGNO, C., 1985, Use of water hyacinths as shelter, foraging place, and transport by young piranhas, Serrasalmus spilopleura. Environ. Biol. Fishes, 12: 237-240.

WINEMILLER, K. O., 1989, Ontogenetic diet shifts and resource partitioning among piscivorous fishes in Venezuelan Llanos. Environ. Biol. Fishes, 26: 177-199. 